With that general framework, let's examine a few specific values and how we might add that value in the materials and services we provide. My idea here is to present a few ideas with the intention of getting you thinking creatively-remember that whack on the side of the head-about adding value: 1) do remote reference for documents CDs; 2) chapter/section analytics; 3) "reference notebook" field, for reference staff to add notes; 4) local title field, for distinctly local titles; 5) Center for Research Libraries records; 6) online journals project; 7) pointer in UTCAT from journals we own to relevant indexing tools; 8) reader levels: basic, undergraduate, advanced, professional; 9) treatment codes: popular, scholarly, applied, theoretical, pictorial, laboratory manual; 10) better options for downgrading from UTCAT; 11) function to identify newly acquired materials in UTCAT.

These are a few ideas for value-added services and options building on the existing infrastructure. As electronic delivery moves into the reference room, whether slowly or quickly, directly or indirectly, there will still be a sig- nificant role for the librarian. As a service organization our role will evolve farther away from warehousing to a higher, more professional level of adding value to materials and services.

Let me leave you with an idea I discovered in a book on telecommunication systems. While the phrases runaway costs and cost overrruns are familiar, think about runaway benefits or benefit overrruns. ${ }^{3}$ Perhaps we can challenge ourselves for the "future of reference" to produce a benefit overrun by value added to our services and materials.

\section{Notes}

${ }^{3}$ Roger Von Oech, $A$ Whack on the Side of the Head: How to Unlock Your Mind for Innovation (New York: Warner Books, 1983).

${ }^{2}$ Robert S. Taylor, Value-Added Processes in Information Systems (Norwood, N.J : Ablex Publishing Corp., 1986), p. 203.

${ }^{3}$ J. L. King, J. L. and K. L. Kraemer, "Cost As a Social Impact of Information Technology" in N. L. Moss ed., Telecommunications and Productivity (Reading, Mass.: Addison-Wesley, 1978), p. 112.

\title{
The future of reference IV: A response
}

\section{by Dennis Dillon}

$\mathbf{N}$ ancy Eaton has given us one version of the future. Here is another.

In 1998, responding to pressure from librarians, academics, publishers, and the general public, Congress approves a one-line change to the tax code. Publishers will now be able to take substantial write-offs for every subscription and book sold to libraries. A $\$ 1,000$ journal now costs libraries $\$ 29.95$. Publishers hail the move as revitalizing the industry, universities praise it as saving scholarly communication, librarians rejoice because it means continued free access to information.

Why did this happen? Because libraries, like schools, hospitals, and roads are what economists refer to as social capital. They are all essential to the functioning of a modern democracy. If citizens want their schools, libraries, and roads improved, politicians will find the money or they won't get reelected. If there are better ways to get information than from libraries, then libraries will get their budgets cut. If publishers, academics, and librarians truly believe that the scholarly communication process is breaking down then this is a societal problem requiring political attention. Will economics be the major determinate of the future library? Of course. When have they not? But it is librarians who will determine what the future library is like. Just as we have in the past, we will make the decision on the information mix and the information services that we will offer.

Will electronic publishing help us put the user and information together? Someday yes. Right now there are a few obstacles, but as Robert Weber has noted, " the chief problems are not technical but political. What is lacking at the moment is a broad consensus that this is the kind of technology infrastructure that would 
substantially enhance education, research, and America's position in the global economy."

But, what if we spend the necessary several billion dollars to rewire the country with optical cable, what if appropriate full-text handling technology is invented, what if human nature suddenly does an about-face on the copyright and royalty problems, and what if all the companies and institutions of the world suddenly decide to cooperate on standards? Where are we then?

Then we are in a world where IBM and AT\&T will have four-color glossy ads in every magazine promising to put the information world at your fingertips. Endearing 30-second ads on television will show little Johnny struggling to get information from the local library where librarians with their hair in buns will give him nothing but excuses and hassles. Every book he needs will be off the shelf. In desperation Johnny will run home in the rain, go to his computer, dial up IBM, and helpful consultants will give him everything he wants instantly. Half an hour later Johnny will be outside playing ball in the sunshine and his unenlightened friend Rodney will still be at the library struggling with the catalog and the CDROMs, and trying to find a copier that works. If electronic publishing truly comes of age, libraries are going to find themselves in direct competition with billion-dollar multinational corporations intent on wringing every possible dime from every conceivable segment of the information market.

This isn't the first time human beings have dealt with many of these same issues and problems. In 1852 the seven major New York newspapers paid over $\$ 9,000$ each for full-text electronic information services. Bankers and brokers along Wall Street were paying between $\$ 500$ and $\$ 1,000$ a year for the delivery of eléctronic information. ${ }^{2}$ Within 15 years there was a handful of electronic information vendors. There were the usual problems with differing standards, protocols, and terminals, but these were eventually resolved. The only thing holding back information nirvana was the design of a user-friendly telegraph terminal and the problem of getting a machine into every household. This dream, however, was interrupted by a more user-friendly technology, the telephone.

Americans have always believed in the smooth and steady march of technological progress. However, the history of technology tells us it isn't always so. Technology progresses in much the same way that a wounded, con- fused, and one-legged chicken crosses the road - in fits and starts with lots of wrong turns, meanderings, and flying feathers. In the long view, yes there is progress, but the short view is dominated by confusion, disorganization, and false starts. That is where the library world is now in regard to coping with online information systems-preparing in confusion to make some false starts and wrong turns.

But just because a technology exists and sounds like a good idea is no guarantee that anyone is going to use it. In 1947 RCA was marketing a fax machine called the Ultrafax that could fax an entire book across country in less than a minute. ${ }^{3}$ However, they soon discovered that no one wanted to send books across country in less than a minute, and the Ultrafax died a quick and unmourned death. 1947 was also the year the FCC had to choose whether the country would have a black-andwhite or a color television system. Both systems had been around for years. The FCC chose RCA's black-and-white system, and a couple of months later the chairman of the FCC left to take a lucrative job with RCA. This is how technology progresses, through political and social filters, and that is why we still have slow fax machines and why it took 20 years for color TV to claw its way back into American living rooms. Eric Sevareid put this all in a nutshell when he said, "Devices change with the times, politics changes with devices; men don't change much with either, but they get temporarily warped out of shape by both."

Libraries could easily be the centerpiece of a future information society, but only if we have the courage to listen to our users and act upon their advice, only if we are willing to lead rather than take the easy way out, only if we experiment and approach every problem with an open mind, and only if we take risks and aren't afraid of making an occasional mistake.

\section{Notes}

${ }^{1}$ Robert Weber, "The Clouded Future of Electronic Publishing,"Publishers Weekly (June 29, 1990), p. 80.

${ }^{2}$ Robert Luther Thompson, Wiring a Continent: The History of the Telegraph Industry in the United States, 1832-1866 (Princeton, N.J.: Princeton University Press, 1947), pp. 217-42.

${ }^{3}$ Maurice Fabre, The History of Communications (New York: Hawthome Books, 1963), p. 97.

${ }^{4}$ Eric Sevareid, This Is Eric Sevareid (New York: McGraw-Hill, 1964), p. 100. 


\section{We'll give you a spectacular view of the science world.}

NEW IN 1992:

Science Citation Index ${ }^{\star}$ Compact Disc Edition with ABSTRACTS

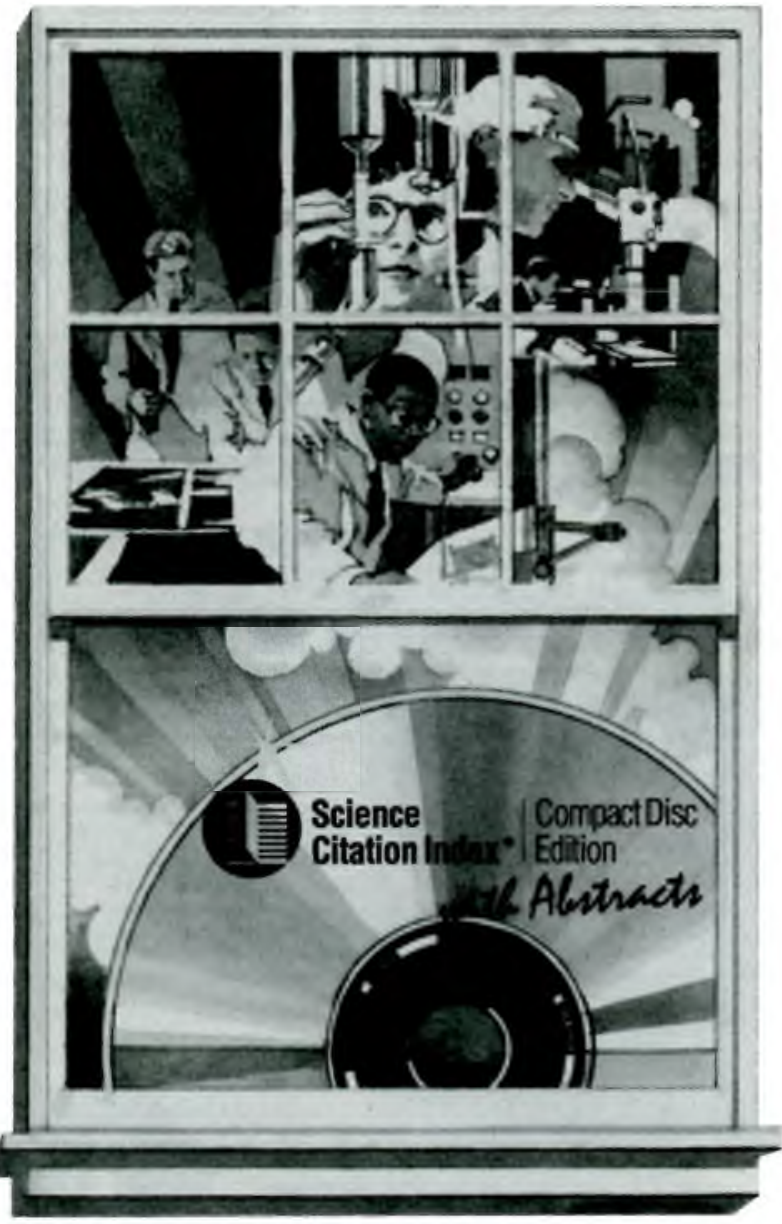

The best thing is, you need go no farther than your computer terminal - where you'll see it all in the Science Citation Index Compact Disc Edition.

With simple keystrokes, you're viewing the bibliographic records of 3,100 leading science journals... and running lightning-fast searches to retrieve data on thousands of research topics.

Another keystroke activates Related Records ${ }^{\mathrm{TM}}$, the powerful searching mechanism available only from ISI ${ }^{\Phi}$. When you find one pertinent article, you're automatically led to many more, even if they have no title words in common! It's information you'd find no other way information that could have a dramatic impact on your research.

And newly available in 1992, searchable abstracts to make your search session even more complete. Reserve a free trial copy or demo diskette of the $\mathrm{SCI}^{\circ}$ CDE by calling 800-336-4474, operator R494, or write the ISI office nearest you.

\section{Institute for Scientific Information ${ }^{8}$}

3501 Market Streel, Philadel phis, PA 19104-3389 U.S.A. Telephone: (215) 386-0100. Fax: (215) 386-2911 ISP European Branch, Brunel University, Uxbridge, UBs 3PH, U.K., Telephone: +44-895-270016 Fax: +44-895-256710 Tolex: 933693 UK|S|

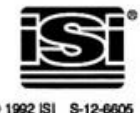




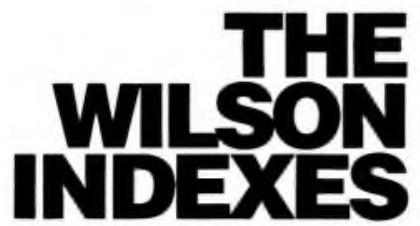

When You Need an Answer Fast and it Has to be Right

Offering broad coverage, unparalleled accuracy, and unmatched currency, the Wilson Indexes are your key to important literature in business and law, science and technology, art, education, the humanities, the social sciences, and general reference.

Now you can search these renowned indexes in print, online, on CD-ROM, and on tape.

\section{G E N E R \\ Bibliographic Index \\ "Recommended for all libraries that use English as the principal language." - AMERICAN REFERENCE BOOKS ANNUAL}

Biography Index

"A dependable and timetested source...basic in reference collections." -AMERICAN REFERENCE BOOKS ANNUAL

\section{Essay and General Literaturelndex}

"A boon to librarians in reference... A must for all academic and large public libraries.'

-AMERICAN REFERENCE BOOKS ANNUAL

Short Story Index

"An indispensable guide for reference work and collection development."

-AMEAICAN REFERENCE BOOKS ANNUAL

\section{Vertical File Index}

- Selected government publications - Charts, posters, \& maps - Art exhibition catalogs - Selected university publications - Selected current topics (from periodicals) - Topics such as energy, taxes, hobbies, personal finance, business, nutrition, health, consumer issues, and travel. Includes Title Index and semiannual cumulated subject index.

Availability

In Print: Eleven monthly issues.

Annual subscription: $\$ 45$ U.S. \& Canada, $\$ 50$ other countries.

Online, CD-ROM, and Tape:

Coverage from 12/85. Not currently available in CD-ROM or tape formats.

To Order, or for more information on these or any of the other Wilson Indexes, simply call toll-free 1-800-367-6770
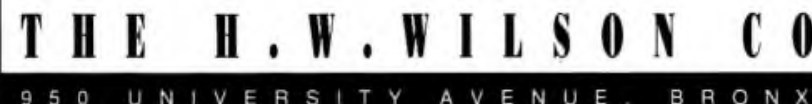